\title{
THE CHALLENGE OF SECULARIZATION TO THE CHRISTIAN BELIEF IN GOD
}

\author{
Jove Jim S. Aguas \\ University of Santo Tomas \\ Manila
}

\begin{abstract}
The secular ideals have impacted on the many aspects of our modern human life but the challenge of secularization is very much felt in the realm of religion especially in Christianity. We can observe that the more society modernizes the level of its religiosity lessens. With the dominance of science, politics and economics in rational discourses and the relevance of technology, the ideology of globalization and the attitude of consumerism and materialism, religious beliefs, practices, values and institutions are losing their relevance to human life and society. Societies whose religious values are historically embedded in their social institutions are continuously moving away from their religious roots towards a nonreligious orientation. In this paper Ifocus on the challenge of secularization and secularism to religion specifically to the Christian belief in God. First, I show that although secularization is a recent phenomenon its philosophical roots can be traced back to the modern times where some Renaissance and Enlightenment thinkers challenged the theocentric discourse of medieval thinkers. This set the stage for secularism as a counter discourse to the medieval belief in God. Second, that out of this modern thinking about God emerged two distinct attitudes towards the question of God - the attitude of the philosophers who although did not totally dismiss the notion of God reduce God to a mere idea or a product of human imagination, and on the other hand the attitude of the believers who continue to believe in the living God. Third, that although one can argue against the position of the non-believing philosophers and counter the position of secularism one appropriate response is self-criticism, that is, for the believers to take a hard look on themselves and see if God and religion are still relevant in their personal and social affairs.
\end{abstract}

\section{NT ROD UCTION}

There was a time in my country, the Philippines when during the Holy Week celebrations there were more people in the church attending the activities commemorat 
ing the passion, death and resurrection of Christ. In the Philippines which is the most predominantly Catholic country in South East Asia the Holy Week is a major religious holiday starting on Palm Sunday until Easter Sunday. Families go home to their respective provinces to observe the Holy Week - a weeklong commemoration spent mostly in prayers and reflection. But now, that has changed; although there are still more people going to the church, there are also more people planning their vacation - going abroad or in some local tourist destination, spending days in the beach or go shopping during the Holy Week. In a country where the influence of the Catholic Church is still strong and where religion has always been part of the social and even political life and where religious values are embedded in the daily life, the secular tendencies are becoming very strong. And such secular tendencies are manifested in the attitude of people during the Holy Week which is supposedly a religious affair or event. This shows the clear challenges of secular tendencies to the religious values of people. The secular ideals have impacted on the many aspects of life in the Philippines especially in the political aspect where there is a constant conflict between the State and the Church, but the challenge of secularization is very much felt in the realm of religious values. This phenomenon is not only present in the Philippines but in many other parts of the world.

\section{THE SECULAR WORLD OF TODAY}

The world of today has clearly progress in terms of communication, convenience and efficiency. It has definitely advanced in terms of business and economics, technology, science and communication. In terms of our living condition we have enjoyed more comforts and convenience. Indeed, when we look at the modern world everything seems to be fine and moving forward; everything seems to be fast and easy. The world now is full of excitement especially for those who are engaged in the social media. The social media has connected us with almost everyone in the planet. We can witness what is going on in the other parts of the world even in real time. But while the modern world has brought us advancement, comfort and convenience it has also created a culture of materialism, consumerism and individualism. A lot of people now put more importance on the material things - gadgets, fancy clothing, expensive cars and accessories. Some people can no longer go without our smartphones, tablets, wallets and all other accessories. Most commonly we go for things that are easy and instant - instant food, instant drinks, and even instant friends - those we just meet on social media. Many things are already measured by individual and economic interests and benefits. In short the world nowadays has become secular.

We can observe that the more society modernizes the level of its religiosity becomes less. With the dominance of science, politics and economics in rational discourses and the relevance of technology, the ideology of globalization and the attitude of consumerism and materialism, our religious beliefs, practices, values and institutions are losing their relevance to human life and society. Due to modernization the role of religion diminishes. Societies whose religious values are historically embedded in their social institutions are continuously moving away from their religious roots towards a non-religious orientation. Such phenomenon of moving away from religion towards a 
non-religious or secular orientation is what we call secularization. Secularization as a phenomenon is based on a philosophical stance which affirms the difference and separation of the religious or sacred from the secular or temporal - secularism. Secularism stresses that religious orientation and considerations must be kept out of temporal or public affairs and vice versa. Religion should not influence public and political affairs as they are two distinct spheres.

While secularization is a worldwide phenomenon, there is no universal and clear definition or meaning of secularization. According to Moojan Momen $(1999,478)$ there are five ways of looking at secularization. First is the decline of popular involvement in institutionalized religion. This can be seen in the decline in church attendance, with fewer marriages, baptisms and funerals being performed under religious auspices. Second is the loss of prestige of religious institutions and symbols and the decline in influence of religious organizations. Third is the separation of society from the religious world, so that religion becomes purely personal matter. Next is the loss of the idea of the sacred. As science increases our understanding of humanity and of the world, the area of 'mystery' and the supernatural also decreases. And lastly religious groups themselves are increasingly becoming concerned with the things of this world rather than the spiritual world. While secularization has made its impact in most parts of the world, it would seem that it is a phenomenon that is more prevalent in those places which embraced the monotheistic religions more particularly Christianity.

\section{THE MEDIEVAL WORLD OF CHRISTIANITY}

If the world of today is becoming more secularized, the medieval world was solidly anchored on the belief in God and Christianity was the dominant authority. At the end of the dominance of Greek philosophy Christianity made its appearance and established itself in the western world as the one true religion, revealed by God and announced to men by Jesus Christ. The early Christian philosophy which is primarily based on Platonic doctrines complemented with the divine revelation and interpreted reality as a creation of the divine being. During the early part of the Middle Ages through the Christian thinkers who were mostly clerics, a theocentric understanding of reality prevailed in the western world. Reality was understood in terms of the theos and the world was understood in terms of the spiritual doctrines and principles. The personal God created the natural or physical world and predestined its course and governed it through the natural law which is based on the eternal law. The social, moral and political aspects of life were understood in the context of the spiritual. The end of human life is the eternal salvation in the next world and such salvation is only possible through faith and grace coming from the divine source - God.

Based on it Judaistic roots Christianity teaches that there is no other God but Yahweh; he is the Creator, the giver of life and the one that sustains all of creations. God is at the center of human existence and of human life. He enters into a relation and communicates with his people giving them protection and guidance. In return $\mathrm{He}$ demands worship and obedience. In such a tradition there is no separation between the 
religious or spiritual dimension and the temporal world. Every part of life is understood as integrated into the religious or spiritual dimension. The whole of human life stands in relation to God, hence, life always takes on a religious meaning. Muslims, like the Jews and Christians, believe in one, unique and incomparable God, whom they address as Allah. The Quran asserts that He is omniscient, omnipotent and omnipresent. He has always existed and will always exist, and the entire cosmos of created beings depend on Him and Him alone for its existence.

Out of the early Christian experience evolved the Christian faith. The formation or development of the Christian faith is a synthesis of the religious experience and the reflective discourse on such experience. In the article "Christianity" John Hick (1967, 246) distinguished between two orders of Christian beliefs and correspondingly, the two orders of such faith - the experiential and the theological. The first order consists of direct accounts of secular and religious experiences and the second consists of theological theories constructed on the basis of these accounts (Hick 1967,246). In the first order, Christian literature affirms a number of both publicly verifiable historical facts and "religious facts," or "facts of faith" (Hick 1967, 246). The religious facts are events in the history of Israel as understood and participated in by the prophets and then later in the life of Jesus and accepted by his apostles. These events are interpreted as revelatory of God. The testimonies of the prophets and apostles are interpreted not as formulations of theological doctrine but direct expressions of moments of intense religious experience (see Hick 1967, 246). The Old Testament and the New Testament are writings on this primary level, recording events that occurred either within the purview of secular history or within the religious experience first by the Jews in the Old Testament and then by the early Christian community in the New Testament.

Although Christianity later emerged into separate sects or branches there are underlying beliefs that provide the core foundation of the Christian faith. There is the belief in one God who manifests Himself in three persons - Father, Son, and Spirit. Next is the belief that God is the Creator of the universe and that by divine act and will $\mathrm{He}$ created this universe from nothing. Together with this universe He created man in His own image and likeness and assigned to man the task of being the steward of His creations. There is the belief that although man was created in the image and likeness of God, man sinned against God. Then there is the belief that because of God's omnibenevolence He sent his Son by divine incarnation in the person of Jesus Christ and who redeemed man of his sinfulness and reconciled man with God. And finally the founding of the Christian church through the Apostles and the Church is continually guided and strengthened by the Spirit. And lastly the eventual end to human history and the fulfillment of God's purpose for his creation.

The second order of Christian belief according to Hick $(1967,246)$ consists in theological theories or doctrines that seek to explain these facts of faith and to relate them to one another and/or to human knowledge in general. The formulation of these doctrines is essentially discursive and rational, the purpose of which is to provide logical or rational basis and interrelations of these doctrines. Hence while the beliefs arecommon to all Christians there are different theories or doctrines that seek to explain 
them. These differences somehow explain the doctrinal differences among the many dominations of Christianity.

The development of Christian thought and faith in the second order during the Middle Ages is intimately related to philosophy. In Introduction: Christianity and Medieval Philosophy (n.d.) the historical and logical development of Christian thought is expressed in three stages. First is the Period of Evangelization, which occupies the entire first century of the Christian era, during which Christianity is diffused as revealed religion, hence containing truth within itself and having no need of rational justification. Second is the Patristic Period, which runs from the beginning of the second century through the eighth century. During this period Christianity was forced to defend itself against the errors which threaten it from without (paganism) and from within (heresies), and the Church Fathers worked out the systematization of the dogmas of Christianity. The third is the Scholastic Period, which runs from the ninth to the sixteenth century. Here Christian thought, utilizing Greek speculation, created its own philosophy in harmony with the dogmatic teaching which had been systematized by the Fathers of the Church. So, only later in the history of Christianity - the Scholastic period, did the early Christians sough for a rational foundation of their Christian faith. Hence, while the main foundation of the Christin belief is faith and the scriptures, Christianity relied heavily on reason if only to provide a rational foundation for such faith.

\section{THE COUNTERDISCOURSE OF THE MODERN THOUGHT}

The early 5th century ushered the advent of the Renaissance which would challenge the prevailing theocentric understanding of reality propounded by the Middle Ages thinkers particularly the Scholastics. The 15 th and 16 th centuries constituted a period of radical social, political, and intellectual developments. The explorations of the world, the Reformation with its emphasis on individual faith, the rise of commercial urban society and the dramatic appearance of new ideas in all areas of culture stimulated the development of a new philosophical world view. The revival of scientific interest in nature was accompanied by a tendency toward pantheistic mysticism which opposed the monotheistic position of the Church. Ironically many Church personalities advocated this new worldview. The Roman Catholic prelate Nicholas of Cusa anticipated the work of the Polish astronomer Nicolaus Copernicus in his suggestion that the earth moved around the sun, thus displacing humanity from the center of the universe; he also conceived of the universe as infinite and identical with God. The Italian philosopher Giordano Bruno, who similarly identified the universe with God, developed the philosophical implications of the Copernican theory. Bruno's philosophy influenced subsequent intellectual forces that led to the rise of modern science and to the Reformation.

Consequently the medieval view of the world based on a hierarchical order of beings created and governed by God was supplanted by the mechanistic picture of the world as a vast machine. According to the mechanistic view, the natural world with all its parts moves in accordance with strict physical laws, without purpose or will coming 
from a divine source. The purpose of human life was no longer conceived as preparation for salvation in the next world, but rather as the satisfaction of people's natural desires. Political institutions and ethical principles ceased to be regarded as reflections of divine command and came to be seen as practical devices created by humans. In this new philosophical view, experience and reason became the sole standards of truth and the basis of the understanding of reality.

The ideals of the Renaissance were further solidified during the Enlightenment period. This vast intellectual movement ushered in a series of changes in European thought and letters and promised a new culture, a new era formed under the guidance of reason or what the thinkers of the time called the "good sense." This new culture and era which developed under the guidance of human reason was in radical contrast to the past ages particularly the Middle Ages. The proponents of Enlightenment considered the Middle Ages as the product of philosophical and religious prejudices which failed to use the light of reason. Hence, the thinkers of the Enlightenment often refer to that age as the age of obscurantism, or the Dark Ages. The new culture with its new brand of philosophy intends to introduce an age of enlightenment through the light of reason to dispel the darkness of the past. The eighteenth century writers claimed that during the Age of Enlightenment, reason made good its promise; it showed the way to progress in science, philosophy and religion, politics and the arts. For them the pure and brilliant light of reason was able to overcome the darkness caused by prejudice, authority and dogma which saddled man during the Middle Ages.

The Enlightenment thought which is based on the Renaissance conceptions paved the way for the secular view of reality. As far as reality is concerned, the universe is interpreted as fundamentally rational and follows mechanical laws. There is no need to refer to God as the creator and the author of the laws that governed it because it can be understood through the use of reason. To know the truth there is no need to reference God because truth can be arrived at through empirical observation, the use of reason and systematic doubt. Human experience particularly sense experience, is the foundation of human understanding of truth. Authority especially religious authority must not be preferred over experience because it is through experience that a fuller view of reality is attained. Religious doctrines which are based on religious authority have no place in the understanding of the physical and human world. As far as human life is concerned, all human life both social and individual can be understood in the same way the natural world can be understood; once understood, human life can be manipulated or transformed in the same way the natural world can be manipulated or transformed.

Through these ideals secularism gained ground in the Christian world of the west. Historically and logically, secularism gained ground during the early stages of the modern era - the Renaissance, and gained momentum through the Enlightenment period. Enlightenment thinkers like Voltaire and Rousseau challenged the authority of the church and religion and modern theorists like Marx, Feuerbach and Weber further stressed the decreasing relevance of religion to human and societal affairs.Consequently secularization has gradually permeated the Christian world. By the nineteenth century, Christianity had ceased to have significant influence on the social and political life of 
Europe. But while secularism first gained ground in the Western Europe it has also spread in the other parts of the world. And it is not only Christianity that has been affected by it because even in Muslim countries there is also the impact of the secular ideals.

\section{TWO UNDERSTANDINGS OF GOD: FROM MODERNISM ONWARDS}

The Renaissance and Enlightenment thinkers did not dismiss religion and the idea of God all together. Religion is part of human life and man had always some sort of belief or idea of God. What they tried to do is to offer an alternative explanation to the idea of God and religion an explanation that challenged the medieval understanding of God based on revelation and Scriptures and the spiritual interpretation of religion. While the divine being was still at the center of religions and of religious discourses in the modern period, for the most part God and religion were being push aside and their relevance in human life and affairs were undermined. Religion was no longer understood in terms of faith, Scriptures and revelation. While God can still be conceived it was no longer at the center of man's personal, social, cultural and religious life. What then emerged in contemporary period are two different understandings of God and consequently of religion - the God interpreted by the philosophers whom some of them deny and the God of the believers with whom the believers relate.

\section{The God of the Philosophers}

In the long history of human thought philosophers have discussed about the nature of God and some have come up with their respective arguments for God's existence. From Socrates, Plato and Aristotle in the ancient times to the medieval thinkers like St. Augustine, St. Albert the Great and St. Thomas Aquinas, to modern thinkers like Descartes, Leibniz, Spinoza, Kant and Hegel, various ideas about God were propounded. In the contemporary period some thinkers have also expressed their views about God, some proclaiming God's greatness and benevolence and some pronouncing his nonexistence even his death. But the question is: what is this God that these philosophers are talking about? What is this God that they define or proclaim or dismiss and deny? Is this God that they are talking about a mere substance, a name, an object or a concept? Is God just a product of man's imagination, some kind of a mental construct, an illusion?

One metaphysical notion of God is that he is a substance and that he exists in reality just like other beings only that he is no ordinary being because he is infinitely powerful and that he is the cause of everything. Benedict Spinoza (1992) writes in his Ethics, (Ip7) that God is a being absolutely infinite, that is, a substance which consists of infinite attributes of which each one expresses the eternal and infinite essence of God. Furthermore, in his Ethics Spinoza (1992) viewed God and Nature as two names for the same reality, namely the single substance which is the basis of the universe and of which all lesser entities are actually modes or modifications. Besides identifying God with nature, Spinoza also deprives God of any qualities of personhood. While God in 
Christianity is considered as a being who thinks, wills, initiates, makes choices, plans, etc. none of these apply to the notion of God of Spinoza, because God is "neither intellect nor will."

Aside from the metaphysical conception, an anthropological conception of God which conceives God as a product of human imagination was also expounded. Ludwig Feuerbach (1881) provides an anthropological interpretation of the notion of God reducing God to a product of human imagination, in other words, God is a man-made conception. For Feuerbach $(1881,14)$ the divine being is nothing else than the human being purified freed from the limits of the individual man and contemplated and revered as another. This conception of God is the basis of religion. According to Feuerbach $(1881,29-30)$ the mystery of religion is that man "projects his being into objectivity, and then again makes himself an object to this projected image of himself thus converted into a subject." What the devout mind worships as God is accordingly nothing but the idea of the human species imagined as a perfect individual. Such position of Feuerbach according to Martin Buber $(1952,68)$ suggests that we should recover for ourselves the creative freedom which we have ascribed to God and that we should affirm ourselves as the being through which the world exists. This anthropological conception of God has been accepted by contemporary thinkers like Marx and Nietzsche. Karl Marx (1976) in his Introduction to A Contribution to the Critique of Hegel's Philosophy of Right contends that God is a man-made invention and that religion is nothing but an "opium of the people" used by the ruling class to make the people feel better and prevent them from knowing that they are just exploited. Marx $(1970,1)$ writes: "Religious suffering is, at one and the same time, the expression of real suffering and a protest against real suffering. Religion is the sigh of the oppressed creature, the heart of a heartless world, and the soul of soulless conditions. It is the opium of the people." Therefore Marx $(1970,1)$ suggests that "the abolition of religion as the illusory happiness of the people is the demand for their real happiness. To call on them to give up their illusions about their condition is to call on them to give up a condition that requires illusions."

Some philosophers have also dismissed God on an existential basis claiming that the belief in God has undermined the potential of man for self-realization. Once we affirm our very own freedom and recover for ourselves our human potentials then there is no need for God anymore. Friedrich Nietzsche (2001) following the thoughts of Feuerbach claims that the belief in God arose because we are unable to have faith in ourselves and so we need to project something out there to which we can cling on. God's existence is an ideology, one of our most persistent illusions. But once we realize the reason for this belief, then religious faith is no longer credible. Nietzsche (2001) in the Gay Science (\# 147) writes: "Once a human being arrives at the basic conviction that he must be commanded, he becomes 'a believer;' conversely, one could conceive of a delight and power of self-determination, a freedom of the will, in which the spirit takes leave of all faith and every wish for certainty, practiced as it is in maintaining itself on light ropes and possibilities and dancing even beside abysses. Such a spirit would be the free spirit par excellence." Nietzsche (1911) in the Twilight of the Idols (Skirmishes, \#4) is more pointed in his critique of Christianity when he remarked: "When we renounce the Chris 
tian faith, we abandon all right to Christian morality.... Christianity is a system, a complete outlook upon the world, conceived as a whole. If its leading concept, the belief in God, is wrenched from it, the whole is destroyed; nothing vital remains in our grasp. Christianity presupposes that man does not and cannot know what is good or bad for him: the Christian believes in God who, alone, can know these things. Christian morality is a command...; it is true only on condition that God is truth,- -it stands or falls with the belief in God." Nietzsche (2006) at the end of Zarathustra's Prologue in Thus Spoke Zarathustra, Zarathustra encounters an aged ascetic who expresses misanthropy and love of God. But when Zarathustra was alone, he spoke thus to his heart: "Could it be possible! This old saint has not heard in his forest that God is dead!" For Nietzsche the belief in God is a burden for society which has outgrown the need for God.

Another existentialist conception of God considers God's existence as incompatible with human freedom. Jean-Paul Sartre thinks that the notion of God is incompatible with human freedom. Sartre's notion of God can be summarized in the following propositions (see Jove Jim Aguas, 2007). First, God as a perfect being is a contradiction because as a perfect being he must be both "en soi" and "pour soi." This would mean that God as an "en soi" is a complete and fixed being and yet an unconscious being and a "pour soi" he is an incomplete but conscious being. Second, the idea of God as a creator denies man of the opportunity to create his own essence through his freedom. Finally, the affirmation of God's existence would negate the recognition of man's freedom. Hence God's existence must be denied. Sartre $(1967,70)$ explains that if man possesses a pre-ontological comprehension of the being of God it is because God, together with value and supreme end of transcendence, represents the permanent limits in terms of which man makes known to itself what he is. Sartre describes God, the Creator like a superior artisan who already has an idea of every object that he creates. Thus every object in his shop follows exactly what he has in mind. God is like a superior artisan and as such, when he creates, knows exactly what he is creating. When God created man he knows exactly the nature of man, and man cannot be but what God created him to be. Hence according to Sartre $(1967,35)$ the individualized man is the realization of a certain concept in the divine intelligence. Sartre strongly opposes such view because that would deprive man of the opportunity to create himself. If God does not exist there is nobody to define human nature. Sartre $(1967,35)$ writes: "If God does not exist, there is at least one being in whom existence precedes essence, a being who exists before he can be defined by any concept and that this being is man."

\section{The God of Abraham, the God of Isaac, the God of Jacob}

The other attitude is that of those who consider God not as an impersonal substance or a mere product of human imagination but as a personal being. Blaise Pascal a gifted scientist and mathematician in a mystical experience one night in 1654 wrote one of the most intense religious experiences of a man of scientific learning. His Memorial (n.d.) written in one scrap paper which was found tucked in the lining of his coat after his death reads: 


\author{
God of Abraham, God of Isaac, God of Jacob, not of the philosophers and \\ learned. \\ Certitude, certitude; feeling, joy, peace. \\ God of Jesus Christ. Deum meum et Deum vestrum. \\ "Thy God shall be my God."
}

This is a something very important for the Christian faith. Those who believe in God do not consider God only as an idea. The God of the believer is different from the God of the philosopher. The God of Christian faith is different from the God of our knowledge. The God of Abraham, the God of Isaac, the God of Jacob that Pascal alludes to is the God of the believer and for the believer his God is not just a concept or a substance that philosophers talk about. There are certainly philosophers who integrated the God of their faith and the God of their knowledge, hence, it cannot be said that the God of the philosopher is totally a different God from the God of Abraham, Isaac and Jacob. St. Augustine, St. Thomas, St. John Paul II just to name a few had integrated reason and faith so that for them the God that they understand and believe is one and the same God. But if we just focus on the God that man can talk about and not the God that man can talk to, then there is something missing in our understanding of God, the living God. According to Buber (1952) God is not an idea or an image; he is a Person to whom we can talk to. If some philosophers have reduced God to the concept or illusion or mere image it is because the God that they considered has been confined to a subjectobject type of relation. But man's relation with God is a subject-subject relation. God is not an object that can just be conceptualized or imagined, he is a subject - an Other we can relate with and we can communicate with. The conception of God as an illusion or a mental contract or a concept or just an image or being, or a silent God reduces God to just a "thing" or an "object" or an "image." For Buber (1958) such conception is based on an I-It relation and not an I-Thou relation. So the question is, is this idea of God of the philosopher the real God that the believer or faithful believes in? Is this the real God being proclaimed by the Christians? Is the God dismissed by the some atheistic philosophers as an illusion or projection of the human mind the living God?

The God proclaimed by Christ or by Mohammed is not an illusion or a product of imagination nor just a concept or image. He is the God whom man can talk to, the God whom man can relate to, the God whom man can communicate and depend on. Many people talk and discuss about God but they do not talk to God. The believer or the faithful may not even know how to speak about God, but he constantly speaks to God. This is precisely what Buber (1952) meant when he made a distinction between knowing God and knowing about God. The person who knows God talks to God, and the person who knows about God, talks about God. So if to believe in God is to be able to talk about him in the third person then for Buber it is not belief, but if to believe is to be able to talk to him then that is true belief. The true God is the God to whom Daniel prayed in his suffering is the real God, the God of all. The God whom the Muslims call Allah is the real God. The real God that believers believe in is a personal God who related and communicates with us. The real God therefore is the not the concept that we discuss in 
philosophy or psychology. Buber (1958) says: "God is the Being that is directly, most nearly, and lastingly over against us, that may properly only be addressed, not expressed."

The problem is human thought has been saturated by "God talk" of the philosophers. And these "God talks" of the philosophers who never even talk to God has caused the disappearance of the real God. It has caused according to Buber (1952) the "eclipse of God," a phenomenon or a situation where the real God has been concealed by the various and often contrasting views and conceptions about God. Philosophers have variedly expressed their own ideas about God projecting God either as an illusion or product of man's imagination or simple a concept or image of an unknown being. While their expositions and analysis are brilliant they may be talking of a different God - the god of their own imagination or conception. For the true believer the God to whom he speaks, to whom he prays is as real as his own very existence. However, because of the many ideas of the philosophers about God the God of the believer has disappeared. There is therefore a need to proclaim the living God whom man encounters in a concrete and living relation in the fullness of his own existence. There is need to distinguish this living God from the "images" and "ideas" of deity projected by the philosophers, the pseudo-gods of reason not only in the context of recent ideologies like secularism but against the background of the thoughts of some great philosophers. What has become secular is not just the world but also the way man understands and relates to God. The understanding of God of the early believers has been supplanted by the modern understanding of God which germinated in the conceptions of the philosophers.

\section{SECULARIZATION IN THE MODERN WORLD}

The contemporary "idea of God" has a provided a basis for the secular attitude towards God and true enough the secular ideals have started from where this "idea of God" has originated - in Europe, and it spread in other parts of the world. According to Filali-Ansary (1996) the pace and exact form of secularization have varied significantly from place to place, depending on a host of political, sociological, economic and other variables. The world's religions have adopted varying responses to it, usually featuring some mixtures of adaptation and self-defense designed to meet the new conditions. In short, societies have shown different ways of responding to the secularizing tendencies. There is one thing common though, religion no longer had a significant role in the shaping of political and social policy. According to Momen $(1999,480)$ "other considerations and other secular ideologies had taken over. Following the loss of social and political influence, religion became increasingly irrelevant to the lives of ordinary people also." It can be said that secularization is not so much the product of the modernization of the world but on the attitude of the modern man towards modernization with all its promise of convenience. The modern man have put his trust and faith in what the modern science and technology can offer instead of putting his faith and trust in religion and God. The value of science and modern living has become more significant than religion and God. If the end of human life is fullness of life, the modern man can 
attains such fullness in other things other than religion and God. So in the modern world, gone is the belief that the fullness of life can only be attained in a life of faith in God.

The Canadian philosopher Charles Taylor (2007) offers an interpretation of secularism. According to Taylor $(2007,25)$ during the early part of the modern era, in 1500 , there were three modes of "God's felt presence in the world" or what he calls the "bulwarks of belief." The first is a sense of God's providence as manifested in the great events of the natural order. In the natural world in which they lived they "testified to divine purpose and action" not just in the way that we understand today the purpose and design of creation. According to Taylor $(2007,25)$ even in the case of natural events which we may consider today as disastrous like storms, droughts, floods and plagues they see these as acts of God in the same manner that fertility and flourishing are seen as acts of God. God's presence is also felt in the very make up society were the associations like city council, and parish were "interwoven with ritual and worship" Taylor 2007,25). And third is in a vivid sense of living in an enchanted world filled with spiritual forces for good and evil. People then may not necessarily have a clear notion of God of monotheism but the Christian God is the ultimate guarantee that good would triumph or at least hold back the forces of evil (see Taylor 2007, 25). By contrast, according to Taylor $(2007,18)$ we now live in a society in which, for the first time in history, "a purely self-sufficient humanism has come to be a widely available option." While our ancestors lived with faith "naively," we must live it "reflectively." "It is this shift in background, in the whole context in which we experience and search for fullness, that I am calling the coming of a secular age." The difference is not just one of creeds but of experience and sensibility.

Taylor (2007, 13-25) opposes the orthodox version of secularization theory that sees the decline in religious belief and practice in our day as caused by the incompatibility of modernity with supernatural religion. While secularization theorists generally focus on a feature of modernization like urbanization or industrialization, the development of class society or the rise of science and technology and regard it as undermining religious faith, Taylor sees reality as not so linear. According to Taylor $(2007,27)$ the rise of modernity is not just a case of loss or subtraction or a case where before we experience "fullness" in God and then in the modern time we lost this "fullness." It is rather in the difference in the way fullness is understood during the medieval or middle ages and the way fullness is understood in the modern times. In the earlier period fullness is understood as a "condition in which our highest spiritual and moral aspirations point us inescapably to God" (Taylor 2007, 27). In the modern period however there is still fullness but this can point to different sources of fullness or alternative sources of fullness and these sources are often referred to as negations of God. The negation of God as the source of our fullness in the past cannot just be attributed to the disappearance of the three modes of God's presence in the world. Taylor $(2007,26)$ argues that fullness can still be experienced in a disenchanted world, in a secular society and in a post cosmic universe. How did these alternatives to the God-reference of fullness arise? The first is the materialistic or naturalistic explanation of the world which 
became an alternative explanation to the God-reference account of the origin of the world. The 15th and 16th century advancement in science offered people an alternative explanation or interpretation of the universe. Science somehow allowed people to see a different view of reality and out of their enchanted view of the universe and paved the way for a kind of humanism and a new sense of self and its place in the cosmos which is no longer vulnerable to the enchanted view of the world, a self which Taylor $(2007,27)$ called the "buffered self." Following this is the society being regarded more in secular terms.

\section{SELF-CRITICISM AS RESPONSE TO SECULARIZATION}

With the contemporary "idea of God" and the advancement of science and technology the place of God in people's lives is no longer that important. More people have put their faith in the progress and good life brought about by scientific and technological advancement. The source of human flourishing and happiness is now placed in the promise of science. At this age of secularism, while the conversation about God is still there, people no longer need and find the notion of God relevant in man's quest for happiness and fullness. What has become secular is not just the world but even the way man has interpreted God. In many ways secularism has undermined one's religious values and view of the world and even how a person views and relates to God. It shakes one's relation with God which is the very foundation of one's beliefs.

Understandably as the modern world becomes secular questions arise as to how we should deal with the advance of the secular ideals. As believers, how do we respond to the challenge of secularization? Should we be critical of the modern society for being secular and for embracing the secular ideal? Should we be critical of some philosophers who have espoused a rather different conception of God? One natural reaction would be to counter this challenge, to defend our values, beliefs and world views from this phenomenon and offer counter arguments against the claim of secularism or even a counter conception to that of other philosophers. Of course such response or reaction is justifiable. If we have to critique the modern society then we should also be critiquing the modern man, and the modern man is not just the one who embraces the secular ideals and the thoughts of some philosophers; the modern man includes the believer as well. Hence one sincere and appropriate response to secularization is to take the claims of secularism and the manifestations of secularization and examine our own beliefs and values against such position. This is not so much of a question addressed to the unbeliever or skeptic or the proponent of secularization but rather to the believer himself. Do we still have the right understanding of who God is? Is God still the center of our life? Is God still the source of value and meaning of existence? Do we still have and practice the right faith? Is religion still valuable in our life? Is religion still focused of the spiritual life of man or has it also become secular in its practice? We may still have faith but God may no longer be at the center of our faith; God may no longer be the central figure in our social and personal life. The practice of religion may have been "commercialized" and that the faithful no longer see the spiritual significance of a 
religious event but its commercial or practical value. Taylor could be right that we have already embraced an alternative source of "fullness" that we still call God, but it is no longer the true living God. So if we claim that God is the center of our life who is the God that we are talking about?

More than the challenges brought about by secularization and the different conceptions about God, the focus should be on the believer or the religious person. Before we can respond to the challenge of secularization we need to have a hard look on ourselves and see if indeed religion and our religious beliefs and values have lost their relevance and are no longer applicable in our life, both in our personal and social affairs. This would mean going back to the core and basic teachings or our faith, most especially our understanding of God. And as we keep that understanding we need to profess in our life that faith - a living faith that is manifested in our thoughts, in our attitude and in our actions in our daily life. But to profess and live our faith is not enough if we want to respond to the challenges of secularization. We need to bear witness to our faith; our life must be the defining difference between the one who believes in the living God and those who reject him.

\section{CONCLUDING REMARKS}

Secularization is not a phenomenon that just suddenly appeared in our world today. The secular ideals evolved or developed through time. It germinated during the renaissance and enlightenment periods and continued to grow during early part of the contemporary period and now it is flourishing in our present world. For the Christian believers and the believers of other faiths or religions it certainly is a challenge. But to confront this challenge the believer must first of all bear witness to his faith or belief. Bearing witness to one's faith does not mean rejecting the world because one's faith or beliefs are expressed and manifested as one exists in the world. As believers, there is no way we can downplay the significance of the world despite its materiality and physicality. The world, as it is, is physical and material and we depend on the world for our physical and biological sustenance. And there are certainly some aspects of the world that attract us. However, we cannot be struck by the glitters of the world and we cannot regard the world with all the scientific and technological advancements as the ultimate basis of human happiness and fullness. There is a spiritual dimension and a real spiritual being who guides us and to whom we relate with. The world is not secular because of its being material or physical. It is man's attitude that has made the world secular; it is man who projected the secular ideals and therefore it is the same man who can change it.

As believers what we need is to take a deep look into ourselves, have a critical self-reflection and see for ourselves the real source of our fullness and happiness, the ultimate source of meaning and value of our life. According to St. Augustine (1958) while we naturally fall in love with the temporal order and material happiness, we need to realize that this is not our final destination. The ultimate end of our journey is union with God. What is needed therefore is to take the world as it is and as part of our journey 
but we need to avoid the distractions of this world and focus on the final end of our journey.

\section{R E F E R E N C ES}

Aguas, Jove Jim. 2007. The incompatibility of God's existence with human freedom: Sartre's existential atheism. Philosophia: International Journal of Philosophy, 31(1). Buber, Martin. 1952. Eclipse of God. New York: Harper Torchbooks. 1958. I and thou. $2^{\text {nd }}$ edition. Translated by Ronald Gregor Smith. New York: Charles Scribner's Sons.

Feuerbach, Ludwig. 1881. The essence of Christianity. London: Trubnee \& Co.

Filali-Ansary, Abdou. 1996. Islam and liberal democracy: The challenge of secularization. Journal of Democracy, 7 (2).

Hick, John. 1967. Christianity. In The Encyclopedia of Philosophy, (2). Edited by Paul Edwards. New York: The Macmillan Company and the Free Press.

Introduction: Christianity and Medieval Philosophy. n.d. http:// www.theradicalacademy.org/adiphilmedieval.html. Accessed June 7, 2017.

Marx, Karl. 1970. Critique of Hegel's philosophy of right. Translated by Joseph O’Malley. Oxford: Oxford University Press.

Momen, Moojan. 1999. Phenomenon of religion: A thematic approach. Oxford: Oneworld Publications.

Nietzsche, Friedrich. 2001. The gay science: With a prelude in German rhymes and an appendix of songs. Edited by Bernard Williams; translated by Josefine Nauckhoff. Cambridge: Cambridge University Press. . 1911. The twilight of the idols. Translated by Anthony Ludovici. Edinburgh and London: T.N. Foulis.

. 2006. Thus spoke Zarathustra. Translated by Adrian del Caro. Cambridge: Cambridge University Press.

Pascal, Blaise. n.d. Memorial. http://inters.org/faith-reason-pascal-memorial. Accessed June 13, 2017.

Sartre, Jean-Paul. 1967. Essays in existentialism. Edited by Wade Baskin. New York: Citadel Press.

Spinoza, Benedict.1992. Ethics. Translated by Samuel Shirley. Indianapolis: Hackett.

St. Augustine. 1958. The city of God. Translated by Gerald Walsh, Demetrius Zema, Grace Monahan and Daniel Honan. New York: Image Books. .

Taylor, Charles. 2007. A secular age. Cambridge: Harvard University Press.

Submitted: 1 May 2018; revised 27 April 2019 